\title{
Intervensi Fisioterapi Yang Efektif Mengurangi Risiko Jatuh LansiaDengan Vertigo, Dizziness, And Balance Disorder
}

${ }^{1}$ Estu Meilani, ${ }^{2}$ Andia Savitri Prabhandari Irham, ${ }^{3}$ Egik Yojana*

${ }^{1}$ Physiotherapy Program, Center for Rehabiliation and Special Needs Studies, Faculty of Health Sciences, Universiti Kebangsaan Malaysia

${ }^{2}$ Bagian Keperawatan, Urusan Rawat Jalan/Rehabilitasi Medik dan Fisioterapi, Rumah Sakit Manyar Medical Centre Surabaya

${ }^{3}$ Program Studi Sarjana Terapan Fisioterapi, Jurusan Fisioterapi, Politeknik Kesehatan Kementrian Kesehatan Surakarta*

Kampus 2 Poltekkes Kemenkes Surakarta, Jalan Kapten Adi Sumarmo, Tohudan, Colomadu, Karanganyar, Jawa Tengah 57173, Indonesia

Email: egikyojana@gmail.com

\begin{abstract}
ABSTRAK
Latar belakang: vertigo, dizziness, and balance disorder (VDB) merupakan kumpulan keluhan yang banyak ditemui pada lansia, dan dapat meningkatkan risiko jatuh. Kejadian jatuh berkaitan erat dengan vertigo dan pening, dimana hal tersebut dapat mempengaruhi activity daily living (ADL). Penulisan artikel ini bertujuan untuk mengetahui intervensi fisioterapi yang efektif mengurangi risiko jatuh pada populasi lansia dengan VDB.

Metode: systematic review dari studi berdesain randomized controlled trial. Kriteria inklusi yaitu artikel dengan: (1) lansia (usia $\geq 60$ tahun) dengan VDB; (2) salah satu parameter pengukuran adalah keseimbangan atau risiko jatuh; (3) studi full-text yang dipublikasikan dalam Bahasa Indonesia atau Bahasa Inggris. Penggunaan artikel yang di inklusi menggunakan Risk of Bias Assessment version 2.0 yang dikembangkan oleh Cochrane.

Hasil: vestibular rehabilitation therapy (VRT) yang dikombinasikan dengan beberapa terapi ratarata memiliki nilai yang signifikan $(\mathrm{p}<0.005)$ dibanding dengan VRT tanpa kombinasi. Latihan keseimbangan + ES dan keseimbangan + biofeedback, menunjukkan nilai yang signifikan dari latihan keseimbangan + biofeedback $(\mathrm{p}=0.003)$. Kombinasi latihan keseimbangan + gait training + anchor menunjukkan tidak ada perbedaan pada skor DHI dan Mini-BESTest. Tai Chi juga memiliki hasil 8 foot up to go test dan LOS yang signifikan.

Kesimpulan: VRT dengan atau tanpa kombinasi, latihan keseimbangan, dan Tai Chi memiliki efek yang baik untuk menurunkan risiko jatuh pada lansia.
\end{abstract}

Kata kunci: vertigo, pening, gangguan keseimbangan, lansia, risiko jatuh

\section{ABSTRACT}

Background: vertigo, dizziness, and balance disorder (VDB) are the most found symptoms in the elderly, increasing the risk of fall. Falls incidence has a strong correlation with vertigo and dizziness, which could also affect daily living activity (ADL). This study aims to find the effective physiotherapy intervention for reduce the risk of fall in elderly population with VDB.

Method: a systematic review of randomized controlled trial studies. The inclusion criteria are articles with: (1) elderly (60 years and older) with VDB; (2) one of the outcome measures is balance or risk of fall; (3) full-text studies published in English or Indonesian. Article quality assessed using Risk of Bias Assessment version 2.0 developed by Cochrane.

Result: vestibular rehabilitation therapy (VRT), which combined with some others therapy mainly has a significant outcome $(\mathrm{p}<0,005)$ compared with VRT without combination. Balance exercise + ES and balance + biofeedback, showed a better outcome rather than balance exercise + biofeedback $(\mathrm{p}=0,003)$. The combination of balance exercise + gait training + anchor showed no significant 
Meilani E., Irham A.S.P., \& Yojana E

Fisiomu.2021 Vol 2(3): 117-132

DOI: $10.23917 /$ fisiomu.v1i3.15064

difference in DHI and Mini-BESTest score, but Tai Chi showed significant result on the 8-foot upto-go test and LOS.

Conclusion: VRT with and without combination, balance exercise, and Tai Chi effectively decrease the risk of fall in the elderly.

Keywords: vertigo, dizziness, balance disorder, elderly, risk of fall

\section{Pendahuluan}

Vertigo, pening, dan gangguan keseimbangan (vertigo, dizziness, and balance disorders, VDB) merupakan kumpulan keluhan yang banyak ditemui pada lansia dengan prevalensi mencapai $50 \%$ dari populasi umum dan meningkat seiring dengan bertambahnya usia.(1)

Pening adalah istilah yang menggambarkan beberapa sensasi diantaranya vertigo spinning atau nonspinning, disequilibrium (ketidakseimbangan), presyncope, kepala terasa ringan, melayang, maupun gabungan dari beberapa hal tersebut. Disamping masih beragamnya penggunaan istilah ini pada kalangan praktisi medis, kebanyakan pasien juga menggunakan istilah pening untuk menggambarkan kondisi lain seperti kelemahan, kelelahan, rasa takut terjatuh, hingga ketidakseimbangan pandangan.(2)

Gangguan keseimbangan atau gangguan stabilitas postural didefinisikan sebagai kondisi dimana tubuh tidak dapat mempertahankan posisinya pada ekuilibrium. Keseimbangan yang paling baik adalah ketika pusat masa tubuh (center of mass, $\mathrm{COM}$ ) atau pusat gravitasi (center of gravity, COG) dipertahankan di atas bidang tumpu (base of support, BOS). Kontrol keseimbangan membutuhkan interaksi secara sistemis antara sistem saraf, muskuloskeletal, dan efek kontekstual. Sistem saraf berperan dalam: (1) pengolahan sensorik yang melibatkan sistem visual, vestibular, dan somatosensorik yang akan melakukan presepsi orientasi ruang tubuh; (2) pelaksanaan gerak volunter oleh integrasi sensorimotor; (3) respon keseimbangan oleh strategi motorik. Sistem muskuloskeletal berperan dalam mempertahankan kesejajaran postural dan fleksibilitas muskuloskeletal seperti lingkup gerak sendi (LGS), integritas sendi, performa otot, serta sensasi. Efek kontekstual merupakan suatu hal yang menghubungkan kerjasama antara sistem saraf dengan sistem muskuloskeletal seperti permukaan penyangga, pencahayaan, efek gravitasi dan gaya inersia tubuh, serta karakteristik tugas yang dilakukan (tugas baru atau kebiasaan dan tingkat kesulitan tugas). Pada lansia, terjadi penurunan fungsi pada seluruh sistem sensorik (somatosensorik, visual, dan vestibular) yang memiliki peran penting dalam mempertahankan keseimbangan tubuh.(3)

Gangguan alat keseimbangan tubuh baik pada sistem vestibular, visual, maupun somatosensori akan menimbulkan gejala vertigo dan disequilibirum (gangguan keseimbangan).(4) Adanya gangguan adaptasi 
Meilani E., Irham A.S.P., \& Yojana E Fisiomu.2021 Vol 2(3): 117-132

DOI: $10.23917 /$ fisiomu.v1i3.15064

postural sebelum melakukan gerak volunter pada lansia dapat menjadi penyebab tingginya insidensi jatuh atau gangguan keseimbangan saat melakukan aktivitas sehari-hari seperti berjalan, mengangkat, serta membawa barang. Kebanyakan kejadian jatuh pada lansia diakibatkan oleh interaksi kompleks beberapa faktor risiko seperti kelemahan otot, riwayat jatuh, gangguan gaya jalan, defisit keseimbangan, penggunaan alat bantu, defisit fungsi visual, gangguan kognitif, serta usia $>80$ tahun.(3)

Dalam kata lain, VDB dapat meningkatkan risiko jatuh pada lansia yang selanjutnya dapat mengakibatkan morbiditas seperti fraktur tulang panggul, cedera otak, bahkan kondisi lain yang lebih fatal. Kecelakaan akibat jatuh menjadi penyebab kematian keenam pada lansia berusia $>75$ tahun. Usia lanjut dengan gangguan keseimbangan memiliki risiko jatuh 2-3 kali dibanding lansia tanpa gangguan keseimbangan, dimana setiap tahun 20-30\% lansia yang berusia >65 tahun sering lebih banyak berada di rumah karena masalah mudah jatuh.(4) Setiap 11 detik, seorang individu dewasa akhir dilarikan ke unit gawat darurat karena jatuh, dan setiap 19 menit, seorang individu dengan usia dewasa akhir meninggal karena jatuh.(2)

Penyebab pasti VDB pada lansia sulit ditentukan karena besar kemungkinan terjadinya gangguan pada sistem vestibular, visual, dan proprioseptif secara bersamaan.(1) Kejadian jatuh berkaitan erat dengan vertigo dan pening, dimana pening dapat menurunkan kualitas hidup individu karena dapat mengakibatkan munculnya kecemasan, penurunan mobilitas, rasa takut terjatuh, terbatasnya aktivitas sehari-hari (activity of daily living, ADL), dan peningkatan biaya perawatan kesehatan secara tidak langsung. Pada lansia dengan usia $>80$ tahun yang dirawat di rumah, 50\% diantaranya mengeluhkan pening.(2)

Kondisi VDB pada lansia, yang diakibatkan oleh diagnosa yang beragam, memerlukan pendekatan rehabilitasi terprogram yang sesuai dengan gejala utama dan bertujuan untuk meningkatkan mobilitas dan partisipasi secara umum.(5) Pilihan intervensi fisioterapi yang berdasar bukti ilmiah mulai berkembang beberapa tahun terakhir dimana intervensi baru berupa virtual reality atau computer-based telah memperluas prespektif fisioterapi.(6) Penulisan systematic review ini bertujuan untuk mengetahui jenis intervensi fisioterapi yang efektif mengurangi risiko jatuh pada lansia dengan VDB.

\section{Metode Penelitian}

Desain penelitian

Studi ini menggunakan desain systematic review dari studi berdesain randomized controlled trial.

\section{Strategi pencarian artikel}

Ketiga penulis melakukan pencarian artikel pada empat database elektronik, yaitu: PEDro, Cochrane Library, Scopus, dan OVID 
Medline. Kata kunci yang digunakan dalam pencarian ini meliputi: elderly, vertigo, dizziness, balance disorder, physical therapy intervention, conventional physical therapy, dan multimodal physical therapy.

\section{Kriteria pemilihan artikel}

Hanya studi dengan desain randomized controlled trial yang dipublikasikan dari bulan Januari 2011 sampai dengan 17 April 2021 yang dilibatkan dalam systematic review ini. Kriteria inklusi artikel adalah sebagai berikut: (1) populasi studi adalah lansia (usia $\geq 60$ tahun) yang mengalami VDB; (2) salah satu parameter pengukuran adalah keseimbangan atau risiko jatuh; (3) studi full-text yang dipublikasikan dalam Bahasa Indonesia atau Bahasa Inggris.

Kriteria yang menyebabkan artikel dieksklusi adalah: (1) populasi studi adalah subyek sehat; (2) studi yang melibatkan intervensi non-fisioterapi seperti operasi dan/atau penggunaan obat.

\section{Penilaian kualitas metodologi artikel}

Penilaian kualitas metodologi setiap artikel yang diinklusi menggunakan Risk of Bias Assessment version 2.0 yang dikembangkan oleh Cochrane dan dapat ditemukan dalam Cochrane handbook 5.1.0.(7)

\section{Ekstraksi data}

Informasi dari setiap artikel yang diekstrak adalah sebagai berikut: karakteristik subyek (jumlah, usia, gender, diagnosa); jenis dan intensitas intervensi pada tiap kelompok
Meilani E., Irham A.S.P., \& Yojana E Fisiomu.2021 Vol 2(3): 117-132 DOI: $10.23917 /$ fisiomu.v1i3.15064

studi; periode observasi; instrumen dan parameter pengukuran/pemeriksaan; dan hasil studi (lihat Tabel 2 dan Tabel 3).

\section{Hasil}

Proses pencarian artikel di keempat database menghasilkan 1.238 artikel. Setelah menghilangkan duplikat, sejumlah 988 artikel diseleksi eligibilitasnya berdasarkan judul, abstrak, dan full-text. Proses seleksi ini akhirnya menghasilkan sembilan artikel untuk dikaji lebih jauh dalam review. Detail proses pemilihan artikel dapat dilihat di PRISMA (Preferred Reporting Items for Systematic Review and Meta-Analysis) flow chart pada Gambar 1.

\section{Karakteristik studi}

Total subyek dalam studi yang terlibat memiliki kisaran antara sembilan hingga 139 yang terbagi dalam dua hingga empat kelompok penelitian. Sebagian besar studi (6/9) mengelompokkan subyeknya dalam dua kelompok, yaitu kelompok eksperimen dan kelompok kontrol, sedangkan tiga studi lainnya membentuk satu hingga dua kelompok lain sebagai kelompok pembanding.(8-10) Rentang rata-rata usia subyek adalah 61,6 hingga 78,68 tahun. Diagnosa subyek pada sebagian besar studi adalah gangguan vestibular (5/9). Karakteristik studi yang lebih lengkap dapat dilihat di Tabel 1. 
Artikel hasil pencarian database elektronik:

$(\mathrm{n}=1238)$

PEDro (48); Cochrane Lib (250);

Scopus (180); Ovid Medline (760)

DOI: $\quad 10.23917 /$ fisiomu.v1i3.15064

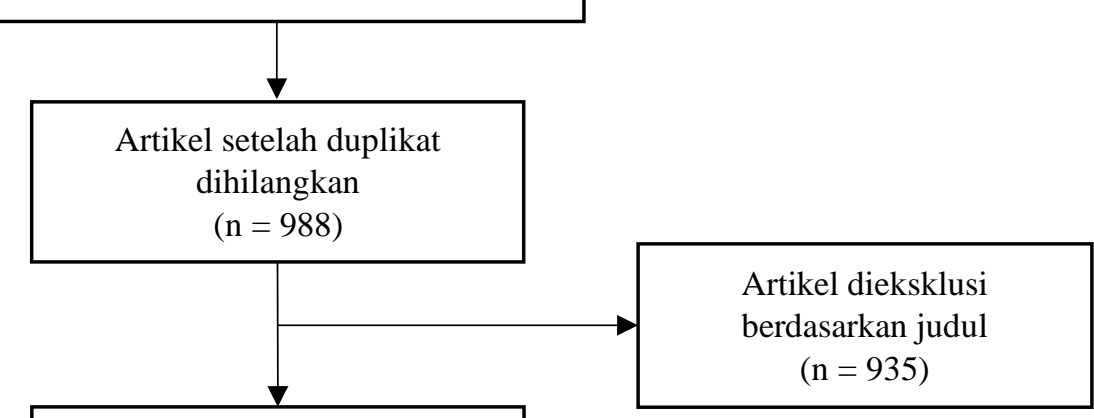

Artikel diseleksi berdasarkan abstrak $(\mathrm{n}=54)$

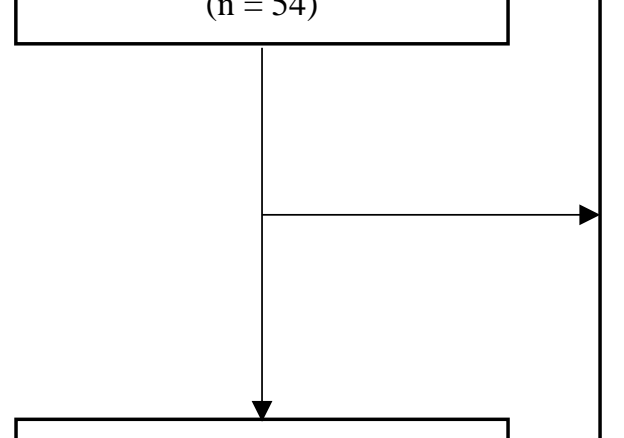

Artikel dieksklusi berdasarkan abstrak, dengan alasan:

$$
(n=34)
$$

- Fokus pada faktor prediktor (1)

- Bukan RCT (5)

- Hasil tidak melaporkan risiko jatuh dan/atau keseimbangan (22)

- Populasi bukan lansia (3)

- Ada modifikasi penggunaan obat (3)

Artikel full-text diseleksi untuk eligibilitas $(\mathrm{n}=20)$

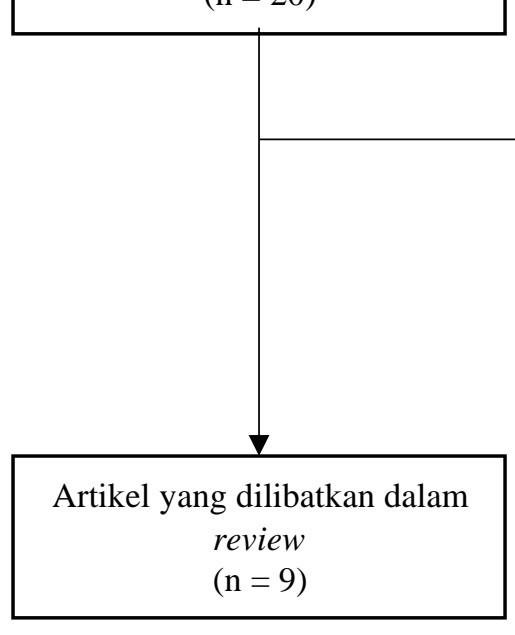

Artikel full-text dieksklusi dengan

$$
\begin{aligned}
& \text { alasan: } \\
& (\mathrm{n}=11)
\end{aligned}
$$

- Populasi bukan VDB (4)

- Populasi bukan lansia (4)

- Bukan RCT (3)

Gambar $1 \quad$ PRISMA flow chart untuk proses seleksi artikel 
Tabel 1 Karakteristik studi

\begin{tabular}{|c|c|c|c|c|c|c|c|c|}
\hline \multirow[b]{2}{*}{$\begin{array}{c}\text { Artikel/Ne } \\
\text { gara (ref) }\end{array}$} & \multicolumn{3}{|c|}{ Karakteristik subjek } & \multicolumn{3}{|c|}{ Intervensi } & \multirow[b]{2}{*}{ Intensitas intervensi } & \multirow[b]{2}{*}{ Observasi } \\
\hline & $\begin{array}{c}n_{\text {total }} \\
\left(\mathbf{n}_{\mathrm{EG}} / \mathbf{n}_{\text {CoG }} / \mathbf{n}_{\mathrm{CG}}\right) \\
; \mathbf{n}_{\text {follow-up(s) }}\end{array}$ & Diagnosa & $\begin{array}{l}\text { Usia (tahun), } \\
\text { Mean } \pm \text { SD } \\
\text { (\%wanita) }\end{array}$ & $\begin{array}{l}\text { Kelompok } \\
\text { Eksperimen } \\
\text { (EG) }\end{array}$ & $\begin{array}{l}\text { Kelompok } \\
\text { Kontrol (CG) }\end{array}$ & $\begin{array}{l}\text { Kelompok } \\
\text { Pembanding } \\
\text { (CoG) }\end{array}$ & & \\
\hline $\begin{array}{l}\text { Alptekin20 } \\
\text { 16/ } \\
\text { Turki (8) }\end{array}$ & $\begin{array}{l}67(23 / 24 / 20) ; \\
57(18 / 19 / 20) \\
48(15 / 17 / 16)\end{array}$ & $\begin{array}{l}\text { Gangguan } \\
\text { keseimbangan } \\
\text { akibat } \\
\text { penurunan } \\
\text { proprioseptif }\end{array}$ & $69,56 \pm 6,55$ & $\begin{array}{l}\text { Latihan } \\
\text { keseimbangan + } \\
\text { biofeedback } \\
\text { training }\end{array}$ & $\begin{array}{l}\text { Latihan } \\
\text { keseimbangan }\end{array}$ & $\begin{array}{l}\text { Latihan } \\
\text { keseimbangan + } \\
\text { ES }^{1} \text { pada otot } \\
\text { postural }\end{array}$ & $\begin{array}{l}\text { EG: } 15 \mathrm{~min} / \mathrm{sesi} \text { selama } 6 \mathrm{mgg} \text { lat } \\
\text { keseimbangan }+15 \mathrm{~min} / \mathrm{sesi} \\
3 \mathrm{x} / \mathrm{mgg} \text { selama } 4 \mathrm{mgg} \text { biofeedback } \\
\text { training } \\
\text { CoG: } 15 \mathrm{~min} / \mathrm{sesi} \text { selama } 6 \mathrm{mgg} \text { lat } \\
\text { keseimbangan }+40 \mathrm{~min} 3 \mathrm{x} / \mathrm{mgg} \\
\text { selama } 4 \mathrm{mgg} \text { ES } \\
\text { CG: } 15 \mathrm{~min} / \mathrm{sesi} \text { selama } 6 \mathrm{mgg} \text { lat } \\
\text { keseimbangan }\end{array}$ & $\begin{array}{l}\text { T0: baseline } \\
\text { T1: 1bln } \\
\text { T2: } 6 \mathrm{bln}\end{array}$ \\
\hline $\begin{array}{l}\text { Bao2019/U } \\
\text { SA (13) }\end{array}$ & $\begin{array}{l}9(4 / 5) \\
8(4 / 4) ; \\
8(4 / 4) \\
8(4 / 4) \\
8(4 / 4)\end{array}$ & $\begin{array}{l}\text { Unilateral } \\
\text { vestibular } \\
\text { disorder }\end{array}$ & $\begin{array}{l}\text { EG: } 68,1 \pm 7,5 \\
(75 \%) \\
\text { CG: } 63,1 \pm 11,3 \\
(75 \%)\end{array}$ & $\begin{array}{l}\mathrm{VRT}^{2}+ \\
\text { vibrotactile } \mathrm{SA}^{3}\end{array}$ & VRT & - & 18 sesi selama $6 \mathrm{mgg}$ & $\begin{array}{l}\text { T0: baseline } \\
\text { T1: mid-training } \\
\text { T2: 1mgg } \\
\text { T3: } 1 \mathrm{bln} \\
\text { T4: } 6 \mathrm{bln}\end{array}$ \\
\hline $\begin{array}{l}\text { Coelho201 } \\
\text { 2/Brazil (9) }\end{array}$ & $\begin{array}{l}42(14 / 14 / 14) ; \\
42(14 / 14 / 14)\end{array}$ & $\begin{array}{l}\text { Vestibulopathy } \\
\text { perifer kronis } \\
\text { unilateral atau } \\
\text { bilateral }\end{array}$ & $\begin{array}{l}\text { EG: } 62,9 \pm 1,12 \\
\text { CoG: } \\
63,8 \pm 2,23 \\
\text { CG: } 61,6 \pm 4,14\end{array}$ & $\begin{array}{l}\text { Latihan } \\
\text { keseimbangan + } \\
\text { gait training + } \\
\text { anchor }\end{array}$ & Tanpa intervensi & $\begin{array}{l}\text { Latihan } \\
\text { keseimbangan + } \\
\text { gait training }\end{array}$ & $45 \mathrm{~min} /$ sesi $2 x / \mathrm{mgg}$ selama $6 \mathrm{mgg}$ & $\begin{array}{l}\text { T0: baseline } \\
\text { T1: post- } \\
\text { intervention } \\
\text { T2: 3bln }\end{array}$ \\
\hline $\begin{array}{l}\text { Maciaszek } \\
\text { 2012/Polan } \\
\text { dia (12) }\end{array}$ & $\begin{array}{l}40(20 / 20) \\
40(20 / 20)\end{array}$ & Dizziness & $\begin{array}{l}\text { EG: } 70,3 \pm 5,9 \\
\text { CG: } 69,1 \pm 5,9\end{array}$ & Tai chi exc & Tanpa intervensi & - & $45 \mathrm{~min} /$ sesi $2 x / \mathrm{mgg}$ selama $18 \mathrm{mgg}$ & $\begin{array}{l}\text { T0: baseline } \\
\text { T1: 18mgg }\end{array}$ \\
\hline $\begin{array}{l}\text { Marioni201 } \\
\text { 3/Italia (14) }\end{array}$ & $\begin{array}{l}28(14 / 14) ; \\
28(14 / 14)\end{array}$ & $\begin{array}{l}\text { Central } \\
\text { vestibular } \\
\text { dysfunction }\end{array}$ & $\begin{array}{l}\text { EG: } 73,9 \pm 8,0 \\
(57,1 \%) \\
\text { CG: } 74,4 \pm 7,3 \\
(57,1 \%)\end{array}$ & $\begin{array}{l}\text { VRT + } \\
\text { posturography }+ \\
\text { home-based exc }\end{array}$ & $\begin{array}{l}\text { Home-based } \\
\text { exc }\end{array}$ & - & $\begin{array}{l}\text { EG: } 30 \mathrm{~min} / \text { sesi selama } 6 \mathrm{mgg} \\
\text { VRT }+3 x / \mathrm{hr} \text { selama } 6 \mathrm{mgg} \text { home- } \\
\text { based exc } \\
\text { CG: } 3 x / \mathrm{hr} \text { selama } 6 \mathrm{mgg} \text { home- } \\
\text { based exc }\end{array}$ & $\begin{array}{l}\text { T0: baseline } \\
\text { T1: } 6 \mathrm{mgg}\end{array}$ \\
\hline $\begin{array}{l}\text { Ribeiro201 } \\
\text { 6/Brazil } \\
(15)\end{array}$ & $\begin{array}{l}14(7 / 7) ; \\
14(7 / 7)\end{array}$ & $\mathrm{BPPV}^{4}$ & $\begin{array}{l}\text { EG: } 69(65-78) \\
\text { CG: } 73(65- \\
76)\end{array}$ & $\begin{array}{l}\text { Modified Epley } \\
\text { CRM }^{5}+\text { VRT }\end{array}$ & $\begin{array}{l}\text { Modified Epley } \\
\text { CRM }\end{array}$ & - & $\begin{array}{l}\text { EG: } 3 x / \text { sesi selama } 13 \mathrm{mgg} \text { CRM } \\
+50 \mathrm{~min} / \mathrm{sesi} 2 \mathrm{x} / \mathrm{mgg} \text { selama } \\
12 \mathrm{mgg} \text { VRT } \\
\text { CG: } 3 x / \text { sesi selama } 13 \mathrm{mgg} \text { CRM }\end{array}$ & $\begin{array}{l}\text { T0: baseline } \\
\text { T1: } 1 \mathrm{mgg} \\
\text { T2: } 5 \mathrm{mgg} \\
\text { T3: } 9 \mathrm{mgg} \\
\text { T4: } 13 \mathrm{mgg}\end{array}$ \\
\hline $\begin{array}{l}\text { Ricci2016/ } \\
\text { Brazil (16) }\end{array}$ & $\begin{array}{l}82(42 / 40) ; 73 \\
(36 / 37) ; 70 \\
(34 / 36) ;\end{array}$ & $\begin{array}{l}\text { Chronic } \\
\text { dizziness akibat } \\
\text { gangguan } \\
\text { vestibular }\end{array}$ & $74(72 \%)$ & MCC $^{6}$ VRT & $\mathrm{CCC}^{7} \mathrm{VRT}$ & - & 50min/sesi 2x/mgg selama 2bln & $\begin{array}{l}\text { T0: baseline } \\
\text { T1: } 8 \mathrm{mgg} \\
\text { T2: } 3 \mathrm{bln}\end{array}$ \\
\hline
\end{tabular}


Meilani E., Irham A.S.P., \& Yojana E Fisiomu.2021 Vol 2(3): 117-132

\begin{tabular}{|c|c|c|c|c|c|c|c|c|}
\hline $\begin{array}{l}\text { Rossi2018/ } \\
\text { Spanyol } \\
(10)\end{array}$ & $\begin{array}{l}139 \\
(35 / 35 / 34 / 35) ; \\
133 \\
(34 / 34 / 30 / 35) ; \\
129 \\
(32 / 34 / 29 / 34) ; \\
103 \\
(29 / 31 / 24 / 29) ; \\
106 \\
(27 / 30 / 21 / 28)\end{array}$ & $\begin{array}{l}\text { Gangguan } \\
\text { keseimbangan } \\
\text { tanpa penyakit } \\
\text { vestibular }\end{array}$ & $\begin{array}{l}\text { EG: } \\
76,98 \pm 7,16 \\
\text { CoG1: } \\
74,34 \pm 5,77 \\
\text { CoG2: } \\
76,83 \pm 6,62 \\
\text { CG: } \\
76,82 \pm 5,74\end{array}$ & $\begin{array}{l}\text { VRT dengan } \\
\text { CDP8 }\end{array}$ & Tanpa intervensi & $\begin{array}{l}\text { CoG1: VRT } \\
\text { dengan } \\
\text { stimulasi } \\
\text { optokinetic } \\
\text { CoG2: home- } \\
\text { based VRT }\end{array}$ & $\begin{array}{l}\text { EG: } 15 \mathrm{~min} / \mathrm{sesi} 5 \mathrm{x} / \mathrm{mgg} \text { selama } \\
2 \mathrm{mgg} \\
\text { CoG1: } 5-15 \mathrm{~min} / \mathrm{sesi} 5 \mathrm{x} / \mathrm{mgg} \\
\text { selama } 2 \mathrm{mgg} \\
\text { CoG2: } 15 \mathrm{~min} / \mathrm{sesi} 2 \mathrm{x} / \mathrm{hr} \text { selama } \\
2 \mathrm{mgg}\end{array}$ & $\begin{array}{l}\text { T0: baseline } \\
\text { T1: 3mgg } \\
\text { T2: 6bln } \\
\text { T3: } 12 \mathrm{bln}\end{array}$ \\
\hline $\begin{array}{l}\text { Smaerup2 } \\
\text { 015/Denm } \\
\text { ark (11) }\end{array}$ & $\begin{array}{l}63(32 / 31) ; \\
60(30 / 30)\end{array}$ & $\begin{array}{l}\text { Gangguan } \\
\text { vestibular } \\
\text { perifer, sentral, } \\
\text { atau campuran }\end{array}$ & $\begin{array}{l}\text { EG: } \\
76,65 \pm 7,56 \\
(58 \%) \\
\text { CG: } \\
78,68 \pm 6,56 \\
(65 \%)\end{array}$ & $\begin{array}{l}\text { Latihan di RS }+ \\
\text { Home-based } \\
\text { exc dengan } \\
\text { computer-based } \\
\text { Mitii program }\end{array}$ & $\begin{array}{l}\text { Latihan di RS + } \\
\text { Home-based } \\
\text { exc } \\
\text { konvensional }\end{array}$ & - & $\begin{array}{l}\text { EG: } 2 \text { sesi/mgg selama } 16 \mathrm{mgg} \\
\text { latihan di RS }+30 \mathrm{~min} / \mathrm{sesi} / \mathrm{hari} \\
\text { selama } 16 \mathrm{mgg} \text { Mitii program di } \\
\text { rumah } \\
\text { CG: } 2 \text { sesi/mgg selama } 16 \mathrm{mgg} \\
\text { latihan di } \mathrm{RS}+30 \mathrm{~min} / \mathrm{sesi} / \mathrm{hari} \\
\text { selama } 16 \mathrm{mgg} \text { latihan di rumah }\end{array}$ & $\begin{array}{l}\text { T0: baseline } \\
\text { T1: } 8 \mathrm{mgg} \\
\text { T2: } 16 \mathrm{mgg}\end{array}$ \\
\hline
\end{tabular}

Catatan: ${ }^{1} \mathrm{ES}=$ electrostimulation; ${ }^{2} \mathrm{VRT}=$ vestibular rehabilitation therapy; ${ }^{3} \mathrm{SA}=$ sensory augmentation; ${ }^{4} \mathrm{BPPV}=$ benign paroxysmal positional vertigo; ${ }^{5} \mathrm{CRM}=$ canalith repositioning maneuver; ${ }^{6} \mathrm{MCC}=$ multimodal cawthorne \& cooksey; ${ }^{7} \mathrm{CCC}=$ conventional cawthorne \& cooksey; ${ }^{8} \mathrm{CDP}$ = computerized dynamic posturography.

Tabel 2 Ringkasan hasil studi dan penilaian RoB

\begin{tabular}{|c|c|c|c|c|c|c|c|c|c|}
\hline \multirow{2}{*}{ Artikel } & \multicolumn{2}{|c|}{ Pengukuran } & \multirow{2}{*}{ Hasil Studi (EG vs CG/CoG) } & \multicolumn{6}{|c|}{ Penilaian Risk of Bias $^{a}$} \\
\hline & Primer & Sekunder & & D1 & D2 & D3 & D4 & D5 & Overall \\
\hline Alptekin2016 & $\begin{array}{l}\text { Keseimbangan: TUG }{ }^{1}, \\
\text { BBS }^{2}, \mathrm{FI}^{3} \text { (Tetrax), WDI } \\
\text { (Tetrax) } \\
\text { Kualitas hidup: WHOQOL- } \\
\text { OLD.TR }{ }^{5}\end{array}$ & Not specified & $\begin{array}{l}\text { vs CoG TUG } \rightarrow-1,42 \text { poin lebih baik }(\mathrm{p}=0,003) \text {; } \\
\text { BBS, FI, WDI, WHOQOL-OLD.TR } \rightarrow \text { tidak ada } \\
\text { perbedaan yg signifikan } \\
\text { vs CG TUG } \rightarrow-1,82 \text { poin lebih baik }(\mathrm{p}=0,003) \text {; } \\
\text { BBS, FI, WDI, WHOQOL-OLD.TR } \rightarrow \text { tidak ada } \\
\text { perbedaan yg signifikan }\end{array}$ & & & & & & \\
\hline Bao2019 & $\begin{array}{l}\text { ABC scale }{ }^{6} \text { DHI }^{7}, \text { SOT }^{8} \\
\text { (computer posturography), } \\
\text { Mini-BESTest }{ }^{9}, \mathrm{FRT}^{10}, \text { Gait } \\
\text { speed test, TUG, DGI }{ }^{11} \text {, } \\
\text { FGA }^{12} \text {, five standing balance } \\
\text { exc }\end{array}$ & Not specified & $\begin{array}{l}\text { ABC scale } \rightarrow \text { interaction effect signifikan }(p<0,05) \text {; } \\
\text { SOT, DGI, Mini-BESTest } \rightarrow \text { main session effect } \\
\text { signifikan }(p<0,05)\end{array}$ & & & & & & \\
\hline Coelho2012 & $\begin{array}{l}\text { Efek dizziness thd ADL }{ }^{13}: \\
\mathrm{DHI}\end{array}$ & $\begin{array}{l}\text { Kecepatan berjalan: step } \\
\text { width }(m), \text { step length }(m), \text { gait } \\
\text { speed }(m / s)\end{array}$ & $\begin{array}{l}\text { vs CoG DHI, Mini-BESTest } \rightarrow \text { tidak ada } \\
\text { perbedaan signifikan }\end{array}$ & & & & & & \\
\hline
\end{tabular}

July $31^{\text {th }}, 2021$ on zoom cloud meeting

Muhammadiyah University of Surakarta, Central Java, Indonesia 


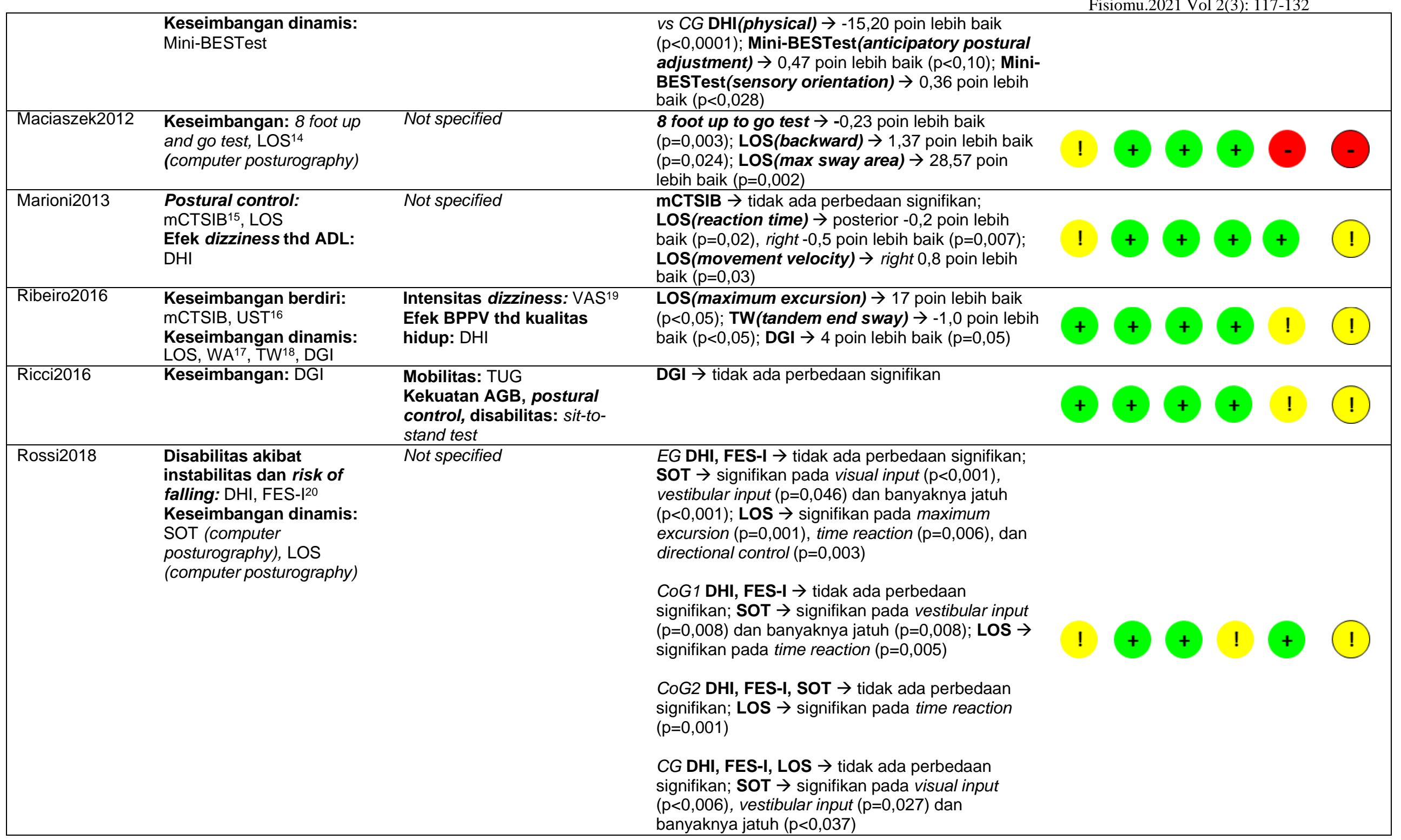

July $31^{\text {th }}, 2021$ on zoom cloud meeting

Muhammadiyah University of Surakarta, Central Java, Indonesia 


\begin{tabular}{|ll}
\hline Smaerup2015 & Postural control: One leg \\
& stand test \\
& Keseimbangan dinamis: \\
& DGl \\
& Efek dizziness thd kualitas \\
& hidup: DHI, SF-12²1 \\
& Dizziness: Motion Sensitivity \\
& Test \\
& Vertigo: VAS \\
& Keseimbangan dan \\
& kekuatan AGB: Chair Stand \\
& Test \\
\end{tabular}

Catatan: $+=$ low risk of bias, $\quad+=$ some concerns, $-=$ high risk of bias; ${ }^{a} \mathrm{D} 1=$ risk of bias arising from the randomization process, $\mathrm{D} 2=$ risk of bias due to deviations from the intended interventions, D3 = risk of bias due to missing outcome data, D4 = risk of bias in measurement of the outcome, $\mathrm{D} 5=$ risk of bias in selection of the reported result; ${ }^{1} \mathrm{TUG}=$ time up and go test; ${ }^{2} \mathrm{BBS}=$ berg's balance scale; ${ }^{3} \mathrm{FI}=$ fall index; ${ }^{4} \mathrm{WDI}=$ weight distribution index; ${ }^{5} \mathrm{WHOQOL} . \mathrm{TR}=$ World Health Organization quality of life scale, older adults module versi Bahasa Turki; ${ }^{6} \mathrm{ABC}$ scale $=$ activities-specific balance confidence scale $;{ }^{7} \mathrm{DHI}=$ dizziness handicap inventory; ${ }^{8} \mathrm{SOT}=$ sensory organization test $;{ }^{9} \mathrm{Mini}-\mathrm{BESTest}=$ mini balance evaluation system test $;{ }^{10} \mathrm{FRT}=$ functional reach test $;{ }^{11} \mathrm{DGI}=$ dynamic gait index; ${ }^{12} \mathrm{FGA}=$ functional gait analysis; ${ }^{13} \mathrm{ADL}=$ activity daily living; ${ }^{14} \mathrm{LOS}=$ limits of stability; ${ }^{15} \mathrm{mCTSIB}=$ modified clinical test of sensory interaction on balance $;{ }^{16} \mathrm{UST}=$ unilateral stance test $;{ }^{17} \mathrm{WA}=$ walk across; ${ }^{18} \mathrm{TW}=$ tandem walk $;{ }^{19} \mathrm{VAS}=$ wisual analog scale $;{ }^{20} \mathrm{FES}-\mathrm{I}=$ short falls efficacy scale-international $;{ }^{21} \mathrm{SF}-12=$ short form-12 questionnaire. 
Meilani E., Irham A.S.P., \& Yojana E

Fisiomu.2021 Vol 2(3): 117-132

\section{Penilaian Risk of Bias (RoB)}

Hasil penilaian RoB pada domain Overall menunjukkan bahwa hanya dua studi $(9,11)$ yang dapat dikategorikan sebagai studi dengan low risk of bias. Enam studi lainnya mendapat nilai some concerns, sedangkan satu lagi studi (12) diketahui memiliki high risk of bias pada domain Overall. Sejumlah tiga artikel $(8,12,13)$ memperoleh nilai high risk of bias pada domain 5, yaitu $R o B$ in selection of the reported result, karena ketiga studi ini menggunakan lebih dari satu parameter parameter untuk melaporkan hasil penelitian mereka. Meskipun demikian, kesemua studi mendapat kategori low risk of bias pada domain 2 dan domain 3. Detail hasil penilaian RoB dapat dilihat di Tabel 2.

\section{Intensitas intervensi}

Durasi latihan yang diberikan pada subyek beragam dari 15 menit hingga 50 menit per sesi terapi. Jumlah sesi per minggu nya juga beragam dari dua hingga lima kali/minggu. Intervensi diberikan selama dua minggu hingga yang paling lama adalah 18 minggu. Detail dosis latihan dapat dilihat di Tabel 1.

\section{Periode observasi}

Semua studi melakukan pengukuran pada baseline atau pengukuran awal sebelum pemberian intervensi. Periode observasi paling singkat adalah satu minggu setelah intervensi $(13,15)$ dan yang paling lama adalah 12
DOI: $\quad 10.23917 /$ fisiomu.v1i3.15064 bulan.(10) Lama periode observasi studi lainnya dapat dilihat di Tabel 1.

\section{Intervensi}

Mayoritas studi (6/9) menggunakan intervensi berupa vestibular rehabilitation therapy (VRT) yang dikombinasikan dengan beragam teknik terapi lainnya. Dua studi menggunakan latihan keseimbangan yang juga dikombinasikan dengan biofeedback training, electrostimulation (ES),(8) gait training, dan gait training+anchor.(9) Satu studi lainnya menggunakan teknik Tai Chi untuk diberikan kepada kelompok eksperimen.(12) Detail jenis intervensi yang diberikan kepada setiap kelompok penelitian dapat dilihat di Tabel 1.

\section{Vestibular rehabilitation therapy (VRT)}

Program VRT yang terdiri dari latihan berdiri, berjalan, dan vestibular ocular reflex (VOR) gaze stabilization exercise dikombinasikan dengan vibrotactile sensory augmentation (SA). SA dapat memberikan isyarat tambahan untuk menambah/mengganti input sensoris dari sistem somatosensoris, visual, dan vestibular. Latihan berdiri dan berjalan diberikan dengan mata terbuka dan tertutup, tipe permukaan berdiri rata dan bergelombang, serta tipe berdiri feet apart/Romberg/semi-tandemRomberg/tandem/satu kaki. Hasil perbandingan dengan kelompok kontrol yang hanya menerima VRT tanpa SA menunjukkan main session effect

July $31^{\text {th }}, 2021$ on zoom cloud meeting

Muhammadiyah University of Surakarta, Central Java, Indonesia 
Meilani E., Irham A.S.P., \& Yojana E Fisiomu.2021 Vol 2(3): 117-132

yang siginifikan pada parameter sensory organization test (SOT), Dynamic Gait Index (DGI), dan Mini Balance Evaluation System Test (Mini-BESTest) $(\mathrm{p}<0,05) .(13)$

Dua studi mengombinasikan VRT dengan posturography. Satu studi mengombinasikan kedua teknik ini dengan homebased exercise dan membandingkannya dengan subyek yang menerima home-based exercise saja. Hasil studi ini menunjukkan bahwa kelompok eksperimen memiliki LOS(reaction time dan movement velocity) -0,5 hingga 0,8 lebih baik dibandingkan kelompok kontrol.(14) Satu studi lainnya membandingkan VRT+posturography dengan VRT+stimulasi optokinetic, home-based VRT, dan kelompok kontrol yang tidak menerima intervensi VRT sama sekali. Studi ini menunjukkan bahwa kelompok eksperimen memiliki hasil signifikan pada lebih banyak parameter dibandingkan kelompok pembanding dan kelompok kontrol. Parameter ini meliputi SOT(visual input, vestibular input, dan banyaknya jatuh) dan LOS(maximum excursion, time reaction, directional control) dengan nilai $\mathrm{p}$ berkisar antara $0,001-0,006 .(10)$

VRT juga dikombinasikan dengan Canalith Repositioning Maneuver (CRM). CRM yang diberikan telah diseuaikan dengan deskripsi oleh Epley (modified Epley CRM) untuk mengurangi gejala pening. Hasil perbandingan dengan kelompok kontrol yang menerima modified Epley CRM saja, menunjukkan bahwa kelompok

DOI: $10.23917 /$ fisiomu.v1i3.15064 LOS(maximum excursion) 17 poin lebih baik $(\mathrm{p}<0,05), \mathrm{TW}$ (tandem end sway) -1 poin lebih baik $(\mathrm{p}<0,05)$, dan skor DGI empat poin lebih baik $(\mathrm{p}=0,05) .(15)$

Perbandingan dua protokol VRT yaitu Conventional Cawthorne \& Cooksey (CCC) dan Multimodal Cawthorne \& Cooksey (MCC) yang diberikan masing-masing pada kelompok penelitian yang berbeda tidak menunjukkan perbedaan skor DGI yang signifikan.(16)

Home-based VRT berbasis komputer (Mitii program) dibandingkan dengan homebased VRT konvensional yang dilakukan dengan memberikan daftar latihan kepada subyek melalui kertas. Mitii program yang diberikan pada komputer setiap subyek telah disambungkan dengan web camera dan sistem latihan melalui Adobe Flash technology. Kedua teknik homebased exercise ini diberikan sebagai tambahan sesi terapi rutin di rumah sakit, akan tetapi perbandingan skor semua parameter pengukuran pada kedua kelompok tidak menunjukkan hasil yang signifikan.(11)

\section{Latihan keseimbangan}

Latihan keseimbangan yang dikombinasikan dengan biofeedback training, dibandingkan dengan kelompok kontrol yang menerima latihan keseimbangan saja dan kelompok pembanding yang menerima latihan keseimbangan+ES pada otot postural. Skor TUG

July $31^{\text {th }}, 2021$ on zoom cloud meeting

Muhammadiyah University of Surakarta, Central Java, Indonesia 
pada kelompok eksperimen menunjukkan -1,42 poin lebih baik $(\mathrm{p}=0,003)$ dibandingkan dengan kelompok pembanding dan $-1,82$ poin lebih baik dibandingkan kelompok kontrol.(8)

Satu studi membandingkan kombinasi latihan keseimbangan+gait training+anchor dengan kelompok pembanding yang menerima latihan keseimbangan+gait training dan kelompok kontrol yang tidak menerima latihan keseimbangan sama sekali. Tidak ada perbedaan skor Dizziness Handicap Inventory (DHI) dan Mini-BESTest yang signifikan pada kelompok eksperimen dan kelompok pembanding. Kelompok eksperimen terbukti memiliki skor $\operatorname{DHI}($ physical) $-15,20$ poin lebih baik $(\mathrm{p}<0,0001)$, Mini-BESTest(anticipatory postural adjustment) 0,47 poin lebih baik $(\mathrm{p}<0,10)$, dan MiniBESTest(sensory orientation) 0,36 poin lebih baik $(\mathrm{p}<0,028)$ dibandingkan kelompok kontrol.(9)

\section{Tai chi}

Kelompok eksperimen yang menerima Tai chi dibandingkan dengan kelompok kontrol yang tidak menerima intervensi sama sekali. Perbandingan dua kelompok penelitian ini menunjukkan bahwa kelompok Tai chi memiliki hasil 8 foot up to go test $-0,23$ poin lebih baik ( $\mathrm{p}=0,003), \operatorname{LOS}$ (backward) 1,37 poin lebih baik $(\mathrm{p}=0,024)$, dan LOS(maximum sway area) 28,57 poin lebih baik.(12)

\section{Pembahasan}

DOI: $\quad 10.23917 /$ fisiomu.v1i3.15064

Artikel ini merupakan systematic review dari beberapa artikel dengan desain studi randomized controller trial, yang bertujuan untuk mengetahui efektifitas program fisioterapi dalam penanganan lansia dengan VDB. Systematic review ini melibatkan subyek dengan tingkat usia elderly yaitu 60 tahun keatas berdasarkan klasifikasi World Health Organization (WHO).

VRT merupakan program yang mencakup empat jenis latihan yaitu latihan keseimbangan, latihan stabilitas pandangan, latihan habituasi, dan latihan berjalan untuk mempertahankan endurance.(13) Menurut studi dalam review ini, VRT sering dikombinasikan dengan teknik terapi lainnya. Upaya kombinasi ini menunjukkan hasil yang lebih baik dibandingkan dengan saat VRT diberikan sebagai terapi tunggal.

Sistem vestibular berkaitan erat dengan gerakan kepala dan gerakan bola mata, oleh karena itu latihan VRT dikombinasi dengan SA yang difokuskan pada gerakan kepala dinamis dan gerakan bola mata dapat meningkatkan reflek vestibular. Reflek vestibular yang baik akan membantu meningkatkan keseimbangan pada lansia, dimana hal tersebut dapat membantu meningkatkan pula kualitas hidup (quality of life, QoL).(13) Kombinasi VRT dengan posturography terbukti lebih menguntungkan bagi pasien dibandingkan dengan pemberian VRT saja karena posturography dapat 
Meilani E., Irham A.S.P., \& Yojana E

Fisiomu.2021 Vol 2(3): 117-132

memberikan penilaian keseimbangan dari beberapa parameter, sehingga terapis dapat mengetahui perkembangan pasien lebih detail.(10,14) Pasien yang menerima kombinasi VRT dengan CRM juga menunjukkan hasil LOS yang lebih baik dibandingkan pasien yang menerima VRT saja. Hal ini menunjukkan bahwa kelompok pasien ini sudah dapat mengontrol gerak ankle dengan lebih baik sehingga kemampuan untuk mengontrol COG juga meningkat. Perkembangan ini dapat menurunkan risiko jatuh pasien.(15)

Disamping hasil VRT kombinasi yang menguntungkan, ada juga studi yang menunjukkan hasil yang tidak signifikan. Hasil perbandingan protokol VRT konvensional dan modifikasi yang tidak menunjukkan perbedaan signifikan membuktikan bahwa apapun protokol yang digunakan, VRT tetap memberikan efek positif terhadap kontrol keseimabangan pada lansia dengan pening.(16) Tidak ditemukannya perbedaan signifikan pengukuran baseline dan post-intervention pada pasien yang menerima home-based VRT konvensional dan Mitii program boleh jadi disebabkan karena kurangnya komunikasi antara terapis dengan pasien. Terapis yang hanya menghubungi pasien sebulan sekali untuk memberikan pengingat pada pasien tentu masih kurang untuk memantau progress latihan pasien.(11)

$$
\text { Tai chi adalah latihan fisik yang }
$$
dikombinasikan dengan meditasi yang bertujuan

maupun mental pasien.(17) Tai Chi menggunakan gerakan-gerakan yang mengharuskan pesertanya fokus dalam menyeimbangkan postur tubuh, oleh sebab itu Tai Chi dapat menghasilkan efek yang positif pada keseimbangan. Hasil penelitian menunjukkan Tai chi memiliki efek yang signifikan terhadap peningkatan keseimbangan dinamis lansia dengan dizziness, yang nantinya juga dapat menurunkan risiko jatuh pada lansia.(12)

Kelebihan dari studi ini adalah mampu memberikan overview tentang berbagai macam latihan untuk lansia dengan VDB, yang kemudian dapat dimanfaatkan oleh pembaca untuk kepentingan klinis atau penelitiann. Akan tetapi, artikel ini masih belum mencakup populasi lansia lainnya yang juga memiliki gejala VDB, misalnya stroke atau parkinson. Hal ini disebabkan karena studi dengan populasi yang spesifik, lansia dengan stroke atau Parkinson yang mengalami VDB, tidak penulis temukan dalam proses pencarian artikel.

\section{Kesimpulan dan Saran}

Dapat disimpulkan bahwa apa saja pendekatan VRT yang diaplikasikan pada pasien, baik VRT yang dikombinasikan dengan teknik terapi lain maupun VRT sebagai terapi tunggal, efektif dalam meningkatkan keseimbangan dan menurunkan risiko jatuh pada lansia dengan VDB. Hasil ini didukung oleh empat dari total 
Meilani E., Irham A.S.P., \& Yojana E Fisiomu.2021 Vol 2(3): 117-132

enam studi mengenai VRT. Selain VRT, Tai chi dan latihan keseimbangan kombinasi juga menunjukkan hasil yang sama menguntungkannya bagi lansia dengan VDB. Secara keseluruhan, kualitas metodologi sebagian besar studi dalam review ini menunjukkan skor some concerns. Oleh karena itu, peneliti dimasa depan diharapkan untuk merencanakan studi dengan lebih matang sehingga dapat menghasilkan studi dengan kualitas metodologi yang lebih baik, sehingga dapat menyediakan evidence yang lebih terpercaya untuk dijadikan pedoman oleh praktisi medis, utamanya fisioterapis.

\section{Daftar Pustaka}

1. Regauer V, Seckler E, Müller M, Bauer P. Physical therapy interventions for older people with vertigo, dizziness and balance disorders addressing mobility and participation: a systematic review. BMC Geriatr. 2020;20(1):1-12.

2. Alyono JC. Vertigo and dizziness: understanding and managing fall risk. Otolaryngol Clin North Am. 2018;51(4):725-40.

3. Kisner C, Colby LA. Therapeutic exercise foundations and techniques. $5^{\text {th }}$ ed. Philadelphia: F. A. Davis Company; 2007.

4. Laksmidewi P, Adnyana IMO, Susilawathi NM, Witari NP, Yuliani D, Gondowardaja Y. Neurology in elderly:
DOI: $10.23917 /$ fisiomu.v1i3.15064 hope for healthy and successful aging. In: 4th Bali Neurology Update. Denpasar: Udayana University Press; 2016.

5. Tjernström F, Zur O, Jahn K. Current concepts and future approaches to vestibular rehabilitation. $\mathrm{J}$ Neurol. 2016;263:65-70.

6. Alghadir A, Iqbal Z, Whitney S. An update on vestibular physical therapy. J Chin Med Assoc. 2013;76(1):1-8.

7. Higgins J, Green S, editors. Cochrane handbook for systematic reviews of interventions version 5.1.0 [updated March 2011] [Internet]. The Cochrane Collaboration; 2011. Available from: www.handbook.cochrane.org

8. Alptekin K, Karan A, Diracoglu D, Yildiz A, Baskent A, Eskiyurt N. Investigating the effectiveness of postural muscle electrostimulation and static posturography feedback exercises in elders with balance disorder. J Back Musculoskelet Rehabil. 2016;29(1):151159.

9. Coelho AR, Fontes RC, Moraes R, Barros CGC, de Abreu DCC. Effects of the use of anchor systems in the rehabilitation of dynamic balance and gait in individuals with chronic dizziness of peripheral vestibular origin: a single-blinded, randomized, controlled clinical trial. Arch Phys Med Rehabil. 2020;101(2):249-257. 
Meilani E., Irham A.S.P., \& Yojana E Fisiomu.2021 Vol 2(3): 117-132

10. Rossi-Izquierdo M, Gayoso-Diz P, Santos-Pérez S, Del-Río-Valeiras M, Faraldo-García A, Vaamonde-SánchezAndrade I, et al. Vestibular rehabilitation in elderly patients with postural instability: reducing the number of fallsa randomized clinical trial. Aging Clin Exp Res. 2018;30(11):1353-61.

11. Smaerup M, Grönvall E, Larsen SB, Laessoe U, Henriksen JJ, Damsgaard EM. Computer-assisted training as a complement in rehabilitation of patients with chronic vestibular dizziness--a randomized controlled trial. Arch Phys Med Rehabil. 2015;96(3):395-401.

12. Maciaszek J, Osinski W. Effect of Tai Chi on body balance: randomized controlled trial in elderly men with dizziness. Am J Chin Med. 2012;40(2):245-253.

13. Bao T, Klatt BN, Carender WJ, Kinnaird C, Alsubaie S, Whitney SL, et al. Effects of long-term vestibular rehabilitation therapy with vibrotactile sensory augmentation for people with unilateral vestibular disorders - A randomized preliminary study. J Vestib Res. 2019;29(6):323-334.
14. Marioni G, Fermo S, Lionello $\mathrm{G}$, Fermo S, Lionello M, Fasanaro E, Giacomelli L, Zanon S, et al. Vestibular rehabilitation in elderly patients with central vestibular dysfunction: a prospective, randomized pilot study. Age. 2013;35(6):2315-2327.

15. Ribeiro KMOB de F, Freitas RV de M, Ferreira LM de BM, Deshpande N, Guerra RO. Effects of balance vestibular rehabilitation therapy in elderly with benign paroxysmal positional vertigo: a randomized controlled trial. Disabil Rehabil. 2017;39(12):1198-206.

16. Ricci NA, Aratani MC, Caovilla $\mathrm{HH}$, Ganança FF. Effects of vestibular rehabilitation on balance control in older people with chronic dizziness: a randomized clinical trial. Am J Phys Med Rehabil. 2016;95(4):256-69.

17. Yogisutanti G, Ardayani $\mathrm{T}$, Simangunsong DSU. Pengaruh senam Tai Chi terhadap fleksibilitas dan kekuatan otot ekstremitas pada lansia di gereja Bandung Barat. JPH Recode. 2018;2(1):60-8. 